\title{
Locational Factors and Foreign Market-entry Considerations for Malaysian Contractors
}

A.-R. Abdul-Aziz and S.S. Wong (School of Housing, Building and Planning, Universiti Sains Malaysia, Penang, Malaysia)

\begin{abstract}
Past studies on contractor internationalisation adopt a unimodel approach. Taking up the call of a few scholars, a study is conducted, this time by integrating several extant models of firm internationalisation. Malaysian international contractors are used to test this approach. Due to space limitation, this paper is focused only on locational factors. It begins by justifying the inclusion of locational factors in a multi-model approach. Then it posits that locational disadvantage is a more intellectually appealing concept than locational advantages. Empirically, it shows that the surveyed contractors evaluate a wide range of factors before making the go/no go decision to enter foreign markets. It also shows that psychic distance was not their major concern. Finally, the locational disadvantages create a market space for international contractors with the tenacity to overcome them, which the sampled population possessed.
\end{abstract}

Keywords: contractor internationalisation, locational disadvantages, multi-model approach, Malaysia.

\section{INTRODUCTION}

There have been various studies that have looked at the internationalisation of contractors from various countries - Britain (Seymour, 1987), South Korea (Chang, 1987; Crosthwaite, 1998; Awil and Abdul-Aziz, 2002) and Singapore (Cuervo and Low, 2003). All have relied on any one of several extant models of firm internationalisation - Eclectic Paradigm, Diamond Model, Stage Growth - for their studies. The uni-model approach conspires against the portrayal of the internationalisation of construction firms as a complex phenomenon since each of these models (and a few more not applied in the construction context), notwithstanding their respective strengths, is limited in its explanatory powers (Abdul-Aziz et al., 2008). Responding to the call by Coviello and McAuley (1999) and Ricart et al. (2004), an integrative or multimodel approach was adopted to further improve our understanding of the subject matter. Malaysian contractors that have gone overseas were used to test the powers of this approach. Due to space limitations, only the locational aspects of contractor internationalisation can be discussed here.

This paper's contribution does not just lie at the conceptual level. International construction contracting is dynamic. In 1998, 20.9\% of the contractors listed in the Engineering News Record Top 225 international contractors were from developing countries (ENR, 1999). Ten years later, the percentage almost doubled to $37.8 \%$ (ENR, 2008). Construction from developing countries has therefore made tremendous strides in the international arena. The presentation of the part-findings of the study shows how contractors from one developing country evaluate foreign markets prior to entry.

The paper begins by reviewing the literature. By examining the various extant firm internationalisation models, the inclusion of locational factors in the proposed multi-model approach is justified. It is suggested that these factors should be conceptualised as locational disadvantages rather than locational advantages. Following on from that, the research method, findings and discussions are presented.

\section{LITERATURE REVIEW}

Of the extant multinational models, only the Stage Growth Theory, Eclectic Paradigm, and more recent Liability of Foreignness (LOF) concept give attention to host market considerations. The Diamond Model (Porter, 1990) and Network Theory (Johanson and Mattson, 1988) apparently do not. This section begins by dwelling on the Stage Growth Theory, followed by the Eclectic Paradigm, Diamond Model and Network Theory. LOF is subsequently considered in further detail when introducing the concept of locational disadvantage.

The Stage Growth Model predicts that companies enter new markets with successively greater psychic distance (Johanson and Vahlne, 1990; Johanson and Wiedersheim-Paul, 1975). Psychic distance refers to language, education, business practice, cultural and even spatial difference between the home and host countries (Johanson and Vahlne, 1977). Psychic distance can be artificially enhanced by visa requirement (Leamer, 1974; Dunning, 1988) and reduced with business interaction between home and host countries (Ferchiou, 1987). The model explains the internationalisation of a firm as an incremental, step-bystep process, from psychically close to more distant locations. A few studies on international contractors have produced varying results on the significance of psychic distance. While Cuervo and Low (2003) and Oz (2001) find that it has a positive impact on Singaporean and Turkish international contractors respectively, Crosthwaite (1998) finds it is only moderately important for British contractors.

For companies to invest abroad, the Eclectic Paradigm states that it must have three advantages: ownership, location and internalisation (Dunning, 1977; 1980; 1981; 1988; 1995; 1998; 2000; 2001). Locational advantages refer to the degree of attractiveness of certain locations over others for the firm to invest in. As hinted above, the Eclectic Paradigm also resorts to the concept of psychic distance to explain country-market choice. Seymour (1987), and more recently Cuervo and Low (2003) and Low and Jiang (2006), adopt the locational advantages concept to generate empirical results pertaining to British and Singaporean contractors respectively.

As mentioned earlier, the Diamond Model (Porter, 1990) and Network Theory (Johanson and Mattson, 1988) make no explicit reference to locational factors. The debate whether locational factors should be included when analysing firm internationalisation has been most intense between Dunning (1993; 1998; 2000) and Porter (1994; 1996; 1998). In one of his publications, Dunning (1998: 60) asserts: 
.... in line with the thinking of Michael Porter (1994; 1996), I believe more attention needs to be given to the importance of location per se as a variable affecting the global competitiveness of firms.

While conceding that "economic geography must move from the periphery to the mainstream" (Porter, 1994: 38), Porter later go on to assert (Porter, 1998: 77):

In theory, more open global markets and faster transportation and communication should diminish the role of location in competition. After all, anything that can be efficiently sourced from a distance through global markets and corporate networks is available to any company and therefore is essentially nullified as a source of competitive advantage.

Porter's (1998: 78) contention is that his Diamond model acknowledges the importance of clusters which implicitly caters for locational issues:

Clusters are not unique, however; they are highly typical - and therein lies a paradox: the enduring competitive advantages in a global economy lie increasingly in local things - knowledge, relationships, motivation - that distant rivals cannot match.

What can be surmised from Porter's argument is that, even without making changes to the Diamond Model, locational issues are already embedded implicitly.

Even with Network Theory (Johanson and Mattson, 1988), some scholars have begun using the term distance, thus acknowledging the importance of the spatial dimension. Chen (2003) for example notes that Taiwan's electronics firms internationalise by first going to close network distance before moving to more distant areas. Network distance is measured by the difficulty of providing network support from the home base taking into account physical distance, shipping convenience, official barriers to the mobility of goods and services, and the compatibility of the network structures between the home base and the host country. Foster and Karin (1998) have likewise used the network distance concept in their work.

Given the coverage of locational factors by various extant models, explicitly or implicitly, an integrated model approach therefore must not ignore their influence on firm internationalisation. Having established so, we posit that it is intellectually more appealing to use the term 'locational disadvantages' than 'locational advantages' to describe factors that influence a firm's decision to enter foreign markets for the simple reason that there are far greater number of features associated with the host countries that deter entry than otherwise (Abdul-Aziz, 1991).

The argument has even been acknowledged by Dunning (1980; 2001), the proponent of the locational advantages concept. Regardless of whether the multinational is resource-seeking, market-seeking, efficiency-seeking, or asset-seeking, Narula and Dunning (1998) concede that the attractions of foreign location are normally confined to one or two factors. Like the present authors, Zaheer (1995) too is less than comfortable with the term locational advantages. Evoking Hymer's (1960) thesis that multinationals face 'foreignness' costs, Zaheer coined the term liability of foreignness (LOF), which has since found favour with several scholars (e.g. Miller and Parkhe, 2002; Chen et al., 2006; Daamen et al., 2007).
Firms going into particular overseas markets, especially for the first time, suffer from a broad range of deterring factors, from spatial distance between home and host countries, unfamiliarity with host country environments, economic nationalism and a lack of legitimacy in the host country to sales restriction impositions by the home country, which can all come under the scope of LOF (Zaheer, 1995; Zaheer and Mosakowski, 1997). Basically, LOF has been defined as all additional costs that a firm operating in a overseas market incurs that a local firm would not incur (Zaheer, 1995). Other scholars have added to the list of sources of LOF (Eden and Miller, 2001). 'Cost' here is the generic term meaning not only various costs but also 'foreignness'; induced hazards and uncertainties that obstruct the generation of earnings (Luo et al., 2002).

As mentioned earlier, only a few locational factors provide attraction to multinationals (Narula and Dunning, 1998). Marketseeking multinationals are drawn to satisfy untapped demand for the products or services in the host country (Narula and Dunning, 1998). Hence the attraction might be market growth (Strassmann, 1970; Wells, 1985; McDougall and Oviatt, 2003; Peck et al., 2005; Zain and Ng, 2006), rapid economic development (Strassmann, 1970; Wells, 1985; Oz, 2001; Coe, 2004; Abdelal and Segal, 2007) and market size (Seymour, 1987; Urata and Kawai, 2000; Andersen and Buvik, 2002; Mayer and Ottaviano, 2008). Efficiency- or asset-seeking multinationals (which are quite similar) seek to utilise sub-national clusters and agglomeration of related activities in the host countries. For resource-seeking, efficiency-seeking and asset-seeking multinationals (Narula and Dunning, 1998), the locational attraction might include good related and supporting industries $(\mathrm{Oz}, 2001$; Cuervo and Low, 2003), technological capability (Hennart, 2000; Cuervo and Low, 2003; Eapen and Hennart, 2005; Rasiah, 2006), level of trained workforce (Urata and Kawai, 2000; Cuervo and Low, 2003; Terjesen and Acs, 2007), ease of funding (Seymour, 1987; Terjesen and Acs, 2007) and infrastructure (Langford, 2000; Khine, 2008). Resource-seeking multinationals seek to exploit scarce resources in the host country (Narula and Dunning, 1998).

Many of the host market features can conspire against the decision to invest in the host country, and for that reason should be termed 'locational disadvantages'. If the cumulative impact of these locational disadvantages outweigh the attraction factors, then the multinational is unlikely to invest in the host country. Locational disadvantages might include industry size (Enright and Roberts, 2001; Awil, 2007), foreign competition (Crosthwaite, 1998) and local competition (Crosthwaite, 1998; Oz, 2001; Borgersen, 2006), cost of doing business (Dunning, 1988; Mpinganjira and Rugimba, 2003; Terjesen and Acs, 2007), capital requirements (Altzinger, 1998; Dung, 1996, Bikker and Wesseling, 2003; Singer, 2004), degree of financial freedom (Solitander, 2005; Quazi, 2007; Kane et al., 2007), exchange rate (Barell and Pain, 1996; Khine, 2008), taxation (Ferchiou, 1987; Galan et al., 1999; Terjesen and Acs, 2007), public sector delivery system and bureaucracy (Barry, 2002; Urata and Kawai, 2000), law and order (Glaister and Atanasova, 1998; Barry, 2002), political scenario (Hillebrandt et al., 1995; Crosthwaite, 1998; Guidotti et al., 2004), degree of market openness (Crosthwaite, 1998; Gunhan and Arditi, 2005) and general host government's policies and behaviour (Chen et al., 2006; Terjesen and Acs, 2007). Some factors may serve to attenuate the locational disadvantages, but on their own are unable to induce foreign investments. These include host government encouragement to multinationals (Glaister and Atanasova, 1998; Cuervo and Low, 2003; Terjesen and Acs, 2007) and financial incentives (Ferchiou, 1987; Galan et al., 1999; Wilkinson et al., 2000). 


\section{RESEARCH METHOD}

The study adopts both qualitative and quantitative methods. Data are triangulated to ensure that the drawn conclusions are strong. Yeung (1995) argue that research in international business requires researchers to consider contextual factors in method selection. The adoption of a mixed method is therefore based on pragmatism in order to best meet the research objectives of uncovering as much as possible about the internationalisation of Malaysian contractors (Johnson and Onwuegbuzie, 2004). The mixed method involves the collection and analysis of both quantitative and qualitative data in a single study in which data are collected concurrently or sequentially, are given priority, and involve the integration of data at one or more stages in the process of research. The advantages of using multiple methods include guarding against the inherent methodological bias (Brewer and Hunter, 1989) and providing opportunity for presenting divergent views (Teddlie and Tashakkori, 2003). Mixed methods have been criticised for their lack of rigour compared to single method approaches (Tashakkori and Teddlie, 2003), however triangulation whereby several sources of data are relied upon helps overcome this weakness (Jicks, 1979).

From the outset, it was decided that getting the cooperation of the Malaysian Construction Industry Development Board (CIDB) was a necessity. CIDB is assigned by a statute to ensure the proper development of the construction industry. Among its responsibilities are the promotion of Malaysian contractors overseas through market-opening initiatives such as trade delegations and matchmaking with local contractors. CIDB maintains a directory of Malaysian contractors that have gone overseas, in all 74 .

Data collection was conducted during three complementary stages. In the first stage, postal questionnaires were sent to all the Malaysian contractors with international experience. Most of the questions in the questionnaire adopted the 5-point Likert scale. A postal questionnaire survey provides greater geographical flexibility and opportunity for the respondent to think about the questions (Cooper and Schindler, 2003). The questionnaires were sent to chief executives or top management of the sample population as they were the best people to answer the questions. The questionnaires were sent out together with a cover letter from the executive of CIDB endorsing the study, thereby lending legitimacy to the study (Sullivan and Bauerschmidt, 1990). The questionnaire was pilot tested by a CIDB senior general manager in charge of construction export promotion. The questions were based on past related empirical and theoretical studies. Fourteen completed questionnaires were returned, representing a response rate of $18.9 \%$. The small sample population can be construed as a limitation of the study. It is symptomatic of the disinterest of the parties to the Malaysian construction industry to academic research which has been experienced from past studies (Mastura and Abdul-Aziz, 2005, Abdul-Aziz, et al. 2006).

The details about the participating companies are summarised in Table 1. Ten of the surveyed contractors were publicly listed while the rest are private limited. Following the UNDP (2007) definition, the majority $(71.4 \%$ : more than 50 employees) were large while the remainder (21.4\%: $20-50$ employees) were medium and $(7.2 \%$ : $5-19$ employees) were small. Only one of the sampled companies had more than ten years international experience, $57.2 \%$ had five to ten years international experience while the rest (35.7\%) had less than five years. The respondents all held high positions, thus enabling them to provide reliable insights about their companies' internationalisation.

The next stage of data collection involved face-to-face interviews with the seven executives who indicated their consent to be interviewed in the returned questionnaires. Face-to-face interviews allow researchers to ask follow-up questions, obtain instantaneous feedback from the respondent and gather further information by observation (Cooper and Schindler, 2003). Before each interview, the returned questionnaires of the would-be interviewees were scrutinised to come up with follow-up questions. Pre-interview desk research about their companies, which marked the third stage of data collection, was also conducted to help design semi-structured questions. With the consent of the interviewees, the interviews were tape-recorded and later transcribed. The questionnaire survey and interviews took place between March and August 2008.

For the data obtained from the postal questionnaires, a nonparametric test (Friedman test) was used to examine for significant differences in the ranking of variables (Laswad and Oyelere, 1999; Kinnear and Gray, 2004; Kazlauskiene and Rinkevicius, 2006). Statistical analysis was undertaken using the statistical package for social science (SPSS). Content analysis was conducted on secondary sources and the transcribed interviews.

As mentioned in the introduction, due to space limitation, only the findings related to locational factors are presented, discussed and analysed in this paper.

Table 1: Surveyed contractor profile

\begin{tabular}{|c|c|c|c|c|c|c|}
\hline Contractor & Legal status & $\begin{array}{l}\text { Year } \\
\text { formed }\end{array}$ & Respondent's position & $\begin{array}{c}\text { Number of } \\
\text { staff }\end{array}$ & Specialisation & $\begin{array}{c}\text { International } \\
\text { experience (Year) }\end{array}$ \\
\hline 1 & public listed & 1975 & chief operating officer & 658 & building \& civil & 10 \\
\hline 2 & private limited & 1994 & director & 35 & sheet piling & 3 \\
\hline 3 & public listed & 1967 & managing director & 200 & mechanical \& electrical & $>10$ \\
\hline 4 & public listed & 1972 & head of department & 5,000 & building \& civil & 8 \\
\hline 5 & public listed & 1974 & chief executive officer & 1,000 & Water supply & 8 \\
\hline 6 & private limited & 1986 & general manager & 30 & building \& civil & 6 \\
\hline 7 & public listed & 1982 & senior general manager & 813 & building \& civil & 5 \\
\hline 8 & public listed & 1974 & executive director & 240 & building \& civil & 2 \\
\hline 9 & private limited & 1993 & senior design engineer & 15 & building \& civil & 10 \\
\hline 10 & public listed & 1981 & assistant manager & 1,200 & building \& civil & 7 \\
\hline 11 & public listed & 1996 & chief financial officer & 40 & building \& civil & 2 \\
\hline 12 & public listed & 1989 & executive director & 178 & building \& civil & 3 \\
\hline 13 & private limited & 1991 & vice president & 500 & building \& civil & 4 \\
\hline 14 & public listed & 1965 & senior manager & 228 & building \& civil & 6 \\
\hline
\end{tabular}

Source: Postal questionnaire survey 


\section{FINDINGS}

Table 2 shows the countries that the surveyed Malaysian contractors had entered. They ranged from being contiguous to distant, developing as well as developed.

Table 3 lists the foreign market-entry considerations as ranked by the sampled population. Market growth and rapid economic development are ranked second and third highest. They can be considered as proxies for local construction demand. One interviewee revealed that his company specifically targets emerging economies. The sixth highest factor is market size. It is interesting to note that market growth and rapid economic development are rated higher than market size as no market, no matter how large it may be, is unattractive without market opportunities. Conversely, large markets with market opportunities can cater for long-term market presence. Following on from that, the market had to be open (ninth highest) for the Malaysian contractors to enter. Size of industry (twelfth highest) is related to competition. In connection to this, foreign (thirteenth highest) rather than local (eighteenth highest) rivals are the concern of the surveyed Malaysian international contractors. One interviewee mentioned that his company avoided competing head-on with contractors from industrialised countries by working in second and third tier cities in China. Host government's encouragement (tenth highest) is a boon, if ever it is available. One interviewee mentions

Table 2: Countries penetrated by surveyed Malaysian contractors

\begin{tabular}{cl}
\hline Contractor & Country \\
\hline 1 & India, Nepal, China, Thailand, UAE, Pakistan, Brunei \\
2 & UAE, Australia, Cambodia, China, Nigeria \\
3 & China, Vietnam, UAE, Qatar, Philippines \\
4 & Singapore, Cambodia, Sudan, Qatar, Yemen, Syria, UK, Denmark, Germany, Sweden \\
5 & Vietnam, Sri Lanka, China \\
6 & South Africa, Maldives, Pakistan \\
7 & India, UAE, Trinidad \& Tobago \\
8 & Pakistan \\
9 & UAE, Vietnam, Singapore, Brunei \\
10 & India, Bahrain, Qatar, UAE \\
11 & Thailand, UAE \\
12 & Saudi Arabia \\
13 & Sudan, Pakistan, Libya \\
14 & India \\
\hline
\end{tabular}

Source: Postal questionnaire survey

Table 3: Factors that Malaysian contractors considered when entering foreign countries

\begin{tabular}{lcc}
\hline \multicolumn{1}{c}{ Variable } & Mean & Rank \\
& rank & \\
\hline Political stability & 19.50 & 1 \\
Market growth & 18.75 & 2 \\
Rapid economic development & 18.50 & 3 \\
Taxation and incentive & 18.17 & 4 \\
Law and order & 17.17 & 5 \\
Market size & 16.92 & 6 \\
Business cost & 16.50 & 7 \\
Financial freedom & 16.50 & 7 \\
Market openness & 16.42 & 9 \\
Host government's encouragement & 16.38 & 10 \\
Ease to get financial funding & 15.67 & 11 \\
Size of the industry & 14.92 & 12 \\
Foreign competition & 14.38 & 13 \\
Government delivery system / bureaucratic efficiency & 14.08 & 14 \\
Government's integrity and transparency & 14.08 & 14 \\
Capital requirement & 13.58 & 16 \\
Exchange rate & 13.50 & 17 \\
Local competition & 12.54 & 18 \\
Related and supporting industries & 12.50 & 19 \\
Infrastructure & 12.17 & 20 \\
Air connection from Malaysia & 11.50 & 21 \\
Technological capability & 11.42 & 22 \\
Geographical distance from Malaysia & 9.54 & 23 \\
Trained workforce & 8.63 & 24 \\
Language and culture similarity & 8.58 & 25 \\
Visa requirement & 8.42 & 26 \\
Degree of business interaction with Malaysia & 7.71 & 27 \\
\hline Source: Postal questionnaire survey & &
\end{tabular}

Source: Postal questionnaire survey

(Chi-Square = 75.71, Asymp. Sig. $=0.000)$ 
that his company was warmly welcomed by the Vietnamese government in search of much-needed foreign investment.

Of most concern to the surveyed Malaysian contractors when going abroad is the political stability of host countries. The same interviewee working for a water supply concession contractor mentions that political stability is particularly crucial as profit can only be recouped over a period of time. Having said that, where others feared to tread, the intrepid would take the calculated risks of operating in these countries in the hope of higher returns. Based on that logic, one surveyed contractor successfully worked in Cambodia and Sudan when they were afflicted with internal strife. The same applied for law and order which is ranked fifth highest. One company went to Nigeria despite the pervasive lawlessness in the country. Thailand and the Philippines can also be unsafe at the worst of times, says one interviewee.

Host government's bureaucracy, and integrity and transparency (both jointly ranked fourteenth highest) which afflicted certain developing countries are less of an issue than political factors. One interviewee comments that Malaysia was worse than in some foreign countries that his company had gone to! Taxation and incentives is the fourth highest ranked factor. Two interviewees advise contractors to properly scrutinise the tax regime of the host country before importing items such as materials, plants and equipment. In a country like India, inter-state disparities could be huge. Conversely countries like the Maldives did not tax building materials imported for construction purpose. Interestingly, business cost and financial freedom are ranked lower (seventh highest) and capital requirement even much lower (sixteenth highest).

Business cost can differ across time: following its accession to the World Trade Organisation, foreign contractors entering China needed at least US\$2 million in paid-up capital unlike the early days of market reform when it was wooing foreign investors, explains one interviewee. Capital requirement can be a concern in countries like Libya and Cambodia where the locals have little confidence in their own currencies, explains another interviewee. Even though it can have an impact on profitability, contractors going abroad have to put up with exchange rate fluctuation (seventeenth highest) and it is therefore ranked fairly low. One interviewee points out that exchange rate needs to be given particular attention when preparing or negotiating final bids.

Of the resources in the host countries which can support field operations, access to funding (eleventh highest) is rated highest, followed by related and supporting industries (nineteenth highest), infrastructure (twentieth highest), technological capability (twentysecond highest), and trained workforce (twenty-forth highest). However, several interviewees point out that the more lacking the host countries are of these resources, the greater the opportunity for the surveyed contractors to make a business impact. For example, the only resource Cambodia has is aggregate and stones; all other construction materials have to be imported, mainly from China. A shortage of skilled labour in the Middle East in particular can be solved by engaging foreign nationals, not necessarily Malaysians.

Factors that either artificially (visa requirement and degree of interaction with Malaysia) or in actuality (geographical and psychic) put distance between Malaysia and the foreign markets are in the bottom five of the list. Although air connection can help bridge distance, its low ranking (twenty-first) is a further indication that the contractors surveyed are not overly concerned with distance. Engaging locals helps to overcome the language and cultural barrier, explained one interviewee.

\section{DISCUSSION}

The discussion examines the empirical findings first before propounding locational disadvantages as a more suitable concept when examining foreign market entry choice.

The data show that when assessing a foreign country, the surveyed Malaysian contractors assessed a whole range of, rather than a few, country-related issues. Based on the literature review, this is to be expected. Venturing overseas is risky (Wang et al., 2004; Gunhan and Arditi, 2005). Construction companies stand to lose a lot of money if they do not assess the host-country characteristics properly. The go/no-go decision must be based on as much information about the country as possible (Han and Diekmann, 2001). SCN Lavalin of Canada, one of the largest construction companies in the world, even has a standard checklist for foreign market assessment purpose (Bebawi, 2008).

The study finds that the surveyed Malaysian contractors venture overseas for the sole purpose of seeking work opportunities abroad. In that sense, they are market-seeking (Narula and Dunning, 1998), which explains why they rate market growth (second ranked) and rapid economic development (third) highly. Past studies on British (Seymour, 1987), Turkish (Oz, 2001) and Singaporean contractors (Cuervo and Low, 2003) also find the same market-seeking trait. Narula and Dunning (1998) make a distinction between market-seeking multinationals and resourceseeking, efficiency-seeking and asset-seeking multinationals. The reality in international construction is that once a construction company secures a project overseas (hence fulfilling its marketseeking tendency), it has to utilise whatever resources and assets are available in the host country as efficiently as possible. And if the resource and assets are inadequate or not to the desired quality, then the contractor has to import them from overseas. The adequacy and quality issue of local resources and assets therefore is not of overriding importance when making market-entry choices. This is reflected in the fairly low ratings for related and supporting industries (nineteenth ranked), infrastructure (twentieth), technological capability (twenty-second), and trained workforce (twenty-fourth). Simply put, in the process of being market-seeking, the surveyed companies have to also be resource-seeking, efficiency-seeking and asset-seeking. The manifestation of these four traits simultaneously (which may not appear in multinationals operating in other economic domains) stems from construction being a location-bound service in that the production-delivery-use chain must be performed on location (Boddewyn et al., 1986). It is this characteristic that can result in manufacturing-biased conceptualisations about multinationals being not entirely suitable to explain the internationalisation of construction companies (Abdul-Aziz, 1995). Also what the findings point to is that the shortages of these needed resources actually created a space for them in the market. It filtered out those international contractors that were able to provide them from those that were not able to.

As indicated in the literature review section, some scholars make great play of psychic distance as being influential in the internationalisation of businesses. The Stage Growth Theory scholars led by Johanson and Vahlne (1990) and Johanson and Wiedersheim-Paul (1975) argue that multinationals enter countries which are psychically close before venturing further afield. Dunning (1977; 1981; 1988) and Zaheer (1995) also incorporate the psychic distance argument in their Eclectic Paradigm and LOF constructs respectively. As pointed out earlier, several studies on different construction nationality groupings have produced mixed results regarding the association between psychic distance and international diversification (Crosthwaite, 1998; Oz, 2001; Cuervo and Low, 2003). The present study finds that psychic distance 
is less of a concern to the sampled population: all the variables that are examined by past scholars to measure psychic distance are at the bottom of the list (see Table 3). Geographical distance (Johanson and Vahlne, 1977; Zaheer, 1995), language and cultural similarity (Johanson and Vahlne, 1977; Zaheer, 1995), visa requirement (Leamer, 1974; Dunning, 1988), and degree of business interaction between host countries and Malaysia (Ferchiou, 1987) are located at the bottom. As the world literally shrinks with globalisation brought about by the internet revolution and 24-hours satellite news, our unfamiliarity with foreign cultures has greatly diminished. And because psychic distance is not a major concern, air connection which helps to bridge geographical distance is also ranked low.

Conceptually, this paper makes the contention that the locational disadvantages concept is more suited than the Eclectic Paradigm's locational advantages argument in portraying the realities of construction contracting when making foreign market entry decisions. The empirical data supports this contention. It has already been established previously that the surveyed Malaysian contractors were primarily market-seeking. The present data supports Narula and Dunning's (1998) own admission that the appeal of foreign locations normally revolves around one or two factors. It is peculiar therefore that the term 'locational advantages' draws attention to the esoteric variables when in fact a far greater number of variables exert countervailing impact on the decision to enter foreign markets. Based on the arguments made in the literature review section and supported from empirical findings, the assertion that locational disadvantage is a more appropriate concept is validated.

Except for factors that can be construed as proxies for construction demand (i.e. market growth, rapid economic development and market size), the rest of the high ranking factors (i.e. political stability, taxation and incentive, law and order, business cost, financial freedom, market opennness, foreign competition, government bureaucracy and government integrity) point to the greater attention the sampled companies gave to locational disadvantages. Host government encouragement which is ranked fairly high merely serves to attenuate the difficulties of working in the host market. The interviews indicate that host encouragements prevailed primarily in developing countries greatly in need of foreign investments, usually after undergoing economic or political reforms. In other words, it was precisely because of the lack of allure that these host governments put in place certain incentives.

When the locational factors are analysed in the proposed manner, an interesting observation can be made, and that is that some of the surveyed contractors turn these locational disadvantages into market opportunities. These locational disadvantages could relate to resource limitation (as pointed out earlier), political instability and personal insecurity, or even unsatisfactory public governance. Some of the countries which the contractors have gone to - Libya, Syria, Pakistan, Nigeria, even Thailand and the Philippines were not exactly politically stable or safe. Countries like India are afflicted with stifling bureaucracy and lack of transparency. Yet, the contractors show willingness to enter those markets drawn by the prospect of making money simply because the more risk averse international contractors avoid them.

\section{CONCLUSION}

This paper's value lies in both its empirical and conceptual contributions. Empirically, the study highlights that the sampled Malaysian contractors considered a wide range of locational factors when considering entering foreign countries. Secondly, that they were market-seeking, which is what most international contractors are. Thirdly, that psychic distance was of relatively low concern when expanding overseas.

It is at the conceptual level that this paper makes a greater contribution. The review of the various extant models of firm internationalisation shows that locational factors cannot be precluded from an integrated model approach for analysing contractor internationalisation. Furthermore locational factors are better conceptualised as locational disadvantages. This marks a radical departure from the Eclectic Paradigm, but augurs well with the LOF concept. When analysing the data in this manner, another contribution of this paper manifests, and that is the sampled Malaysian contractors commercially exploited the locational disadvantages of host countries by overcoming them when the more risk-averse contractors shun them.

\section{ACKNOWLEDGEMENTS}

The authors would like to thank Universiti Sains Malaysia for funding the research which has resulted in the production of this paper.

\section{REFERENCES}

Abdelal, R. and Segal, A. (2007) 'Has globalization passed its peak?', Foreign Affairs, 86(1), 103-108.

Abdul-Aziz, A.-R. (1991) 'Global strategies of construction firms', Ph.D thesis, University of Reading.

Abdul-Aziz, A.-R. (1995) 'Examination of the eclectic paradigm as applied to international contracting: With emphasis on the internalisation dimension', Engineering, Construction and Management, 2(2), 105-120.

Abdul-Aziz, A.-R., Jaafar, M. and Ho, S.-Y. (2006) 'Resourcebased view and critical success factors: A study on small and medium sized contracting enterprises (SMCEs) in Malaysia', The International Journal of Construction Management, 5(2), 61-77.

Abdul-Aziz, A.-R, Wong, S.-S. and Awil, A.-U. (2008) 'Formulating a holistic model to describe international diversification of construction companies', in proceedings of Conference on Building Abroad: Procurement of Construction and Reconstruction Projects in the International Context, IF Research Group and University of Montreal, Montreal, Canada, 23-25 Oct.

Altzinger, W. (1998) 'Austria's foreign direct investment in Central and Eastern Europe: Supply based or market driven?', Working Paper 57, Vienna University of Economics and Business Administration.

Andersen, O. and Buvik, A. (2002) 'Firms' internationalization and alternative approaches to the international customer/market selection', International Business Review, 11(3), 347-363.

Awil, A.U. (2007) 'Internationalisation of the housing development sector: A study of the Malaysian scenario', Ph.D thesis, School of Housing, Building and Planning, Universiti Sains Malaysia, Penang, Malaysia.

Awil, A.U. and Abdul-Aziz, A.-R. (2002) 'International markets: Malaysian contruction contractors and the stage theory', The Australian Journal of Construction Economics and Building, 2(1), 94-106. 
Barrell, R. and Pain, N. (1996) 'An econometric analysis of U.S. foreign direct investment', Review of Economics and Statistics, $78(2), 200-207$.

Barry, F. (2002) 'EU accession and prospective FDI flows to CEE countries: A view from Ireland', Working paper, (August), mimeo., University College Dublin, Dublin.

Bebawi, W. S. (2008) 'International construction contracts: Risks assessment', in proceedings of Conference on Building Abroad: Procurement of Construction and Reconstruction Projects in the International Context, IF Research Group and University of Montreal, Montreal, Canada, 23-25 Oct.

Bikker, J. and Wesseling, S. (2003) 'Intermediation, integration and internationalisation: A survey on banking in Europe', Occasional Studies, 1(3), De Nederlandsche Bank. Retrieved 9 April, 2009 from http://www.dnb.nl/binaries/os3_tcm46-146639.pdf.

Boddewyn, J.J., Halbrich, M.B. and Perry, A.C. (1986) 'Service multinationals: Conceptualisation, measurement and theory', Journal of International Business Studies, 17(3), 41-57.

Borgersen, T.-A. (2006) 'When experience matter: The export performance of developing countries' SMEs', Journal of Sustainable Development in Africa, 8(1), 106-118.

Brewer, J. and Hunter A. (1989) 'Multi-method research: A synthesis of styles', Sage Library of Social Research, 175, Newbury Park: Sage Publications.

Chang, D.-W. (1987) 'Performance of the Korean construction firms in the Middle East', Ph.D thesis, New York University, New York.

Chen, T.J. (2003) 'Network resources for internationalisation', Journal of Management Studies, 40(5), 1107-1129.

Chen, H., Griffth, D.A. and Hu, M.Y. (2006) 'The influence of liability of foreignness on market entry strategies: An illustration of market entry in China', International Marketing Review, 23(6), 636-649.

Coe, N.M. (2004) 'The internationalisation/globalisation of retailing: Towards an economic-geographical research agenda', Environment and Planning A, 36(9), 1571-1594.

Cooper, D.R. and Schindler, P. S. (2003) Business research methods ( $8^{\text {th }}$ Edition), New York: Mc-Graw Hill.

Coviello, N.E. and McAuley, A. (1999) 'Internationalisation and the smaller firm: a review of contemporary empirical research', Management International Review, 39(2), 223-257.

Crosthwaite, D. (1998) 'The internationalization of British construction companies 1990-96: An empirical analysis', Construction Management and Economics, 16(4), 389-395.

Cuervo, J.C. and Low, S. P. (2003) 'Significance of location factors for Singapore transnational construction corporations', Engineering, Construction and Architectural Management, 10(5), 342-353.

Daamen, B., Hennart, J.-F., Kim, D.-J. and Park, Y.-R. (2007) 'Sources of and responses to the liability of foreignness: The case of Korean companies in the Netherlands', Global Economic Review, 36(1), 17-35.
Dung, N.T. (1996) 'Foreign direct investment in Vietnam', in S. Leung (ed.), Vietnam assessment: Creating a sound investment climate, London: Curzon Press, 69-89.

Dunning, J.H. (1977) 'Trade, location of economic activity and the MNE: A search for an eclectic approach', in B. Ohlin, P.O. Hesselborn and P.M. Wijkman (eds), The international allocation of economic activity, London: Macmillan Press Ltd, 395-431.

Dunning, J.H. (1980) 'Toward an eclectic theory of international production: Some empirical tests', Journal of International Business Studies, 11(1), 9-31.

Dunning, J.H. (1981) 'Explaining the international direct investment position of countries: Towards a dynamic or developmental approach', Weltwirtschaftliches Archiv (Review of World Economics, Journal of the Kiel Institute of World Economics), 117(1), 30-64.

Dunning, J.H. (1988) Explaining international production, London: Unwin Hyman Ltd.

Dunning, J.H. (1993) 'Internationalizing Porter's Diamond', Management International Review, 33(2), 7-15.

Dunning, J.H. (1995) 'Reappraising the eclectic paradigm in an age of alliance capitalism', Journal of International Business Studies, 26(3), 461-491.

Dunning, J.H. (1998) 'Location and the multinational enterprise: A neglected factor?', Journal of International Business Studies, 29(1), 45-56.

Dunning, J.H. (2000) 'The eclectic paradigm as an envelope for economic business theories of MNE activity', International Business Review, 9(2), 163-190.

Dunning, J.H. (2001) 'The eclectic (OLI) paradigm of international production: Past, present and future', International Journal of the Economics of Business, 8(2), 173-190.

Eapen, A. and Hennart, J.-F. (2005) 'Entering India: Licensing or joint venture?', Competitive Paper, 28th EIBA Annual Congress, December 8 - 10, Athens, retrieved 8 April, 2009 from http://www. aueb.gr/deos/EIBA2002.files/PAPERS/C103.pdf.

Eden, L. and Miller, S.R. (2001) 'Opening the black box: The multinational enterprise and the costs of doing business abroad', in Best Paper Proceedings, Academy of Management.

ENR (1999) 'The top 225 international contractors', Engineering News Record, 243(7), 52-71.

ENR (2008) 'The top 225 international contractors', Engineering News Record, 261(5), 32-37.

Enright, M.J. and Roberts, B.H. (2001) 'Regional clustering in Australia', Australian Journal of Management, 26 (Special Issue), 65-86.

Ferchiou, R. (1987) 'Tunisia'. Strassmann, W.P., and Wells, J. (Eds), The global construction industry: Strategies for entry, growth and survival, London: Unwin Hyman, 199-210. 
Foster, O. and Karin, H. (1998) 'Internationalisation and networks. The case of an intermediary company in promoting business links between Ghana and Finland', in proceedings of $14^{\text {th }}$ IMP Annual Conference Proceeding, Interaction, relationships and networks: Visions for the future, vol 3, 282-302.

Galan, J.I., Galende J. and Gonzalez-Benito J. (1999)

'Determinants of international development: Some empirical evidence', Management Decision, 37(10), 778-785.

Glaister, K.W. and Atanasova, H. (1998) 'Foreign direct investment in Bulgaria: Patterns and prospects', European Business Review, 98(2), 122-134.

Guidotti, P.E., Rojas-Suarez, L. and Zahler, R. (2004) 'Designing financial regulatory policies that work for Latin America: The role of markets and institutions, views from the Latin American Shadow Financial Regulatory Committee', Journal of Financial Stability, 1(2), 199-228.

Gunhan, S. and Arditi, D. (2005) 'Factors affecting international construction', Journal of Construction Engineering and Management, 131(3), 273-282.

Han, S.H. and Diekmann, J.E. (2001) 'Approaches for making risk-based go-no-go decision for international projects', Journal of Construction Engineering and Management, 127(4), 300-308.

Hennart, J.-F. (2000) 'Transaction costs theory and the multinational enterprise', in C. Pitelis and R. Sugden (eds.), The nature of the transnational firm ( $2{ }^{\text {nd }}$ Edition), London: Routledge, 72-118.

Hillebrandt, P., Cannon, J. and Lansley, P. (1995) The construction company in and out of recession, London: Macmillan.

Hymer, S. (1960) The international operations of national firms: $A$ study of direct investment, Cambridge, Massachusetts: MIT Press.

Jicks, T.D. (1979) 'Mixing qualitative and quantitative methods: Triangulation in action', Administrative Sciences Quarterly, 24, 602-611

Johanson, J. and Mattsson, L.G. (1988) 'Internationalisation in industrial systems-a network approach', in N. Hood and J.E. Vahlne (eds.), Strategies in global competition, London: CroomHelm, 287-314.

Johanson, J. and Vahlne, J.-E. (1977) 'The internationalization process of the firm: A model of knowledge development and increasing foreign market commitments', Journal of International Business Studies, 8(1), 22-32.

Johanson, J. and Vahlne, J.-E. (1990) 'The mechanism of internationalisation', International Marketing Review, 7(4), 11-24.

Johanson, J. and Wiedersheim-Paul, F. (1975) 'The internationalization of the firm: Four Swedish cases', Journal of Management Studies, 12(3), 305-322.

Johnson, B. and Onwuegbuzie A.J. (2004) 'Mixed methods research: A research paradigm whose time has come', Educational Researcher, 33(7), 14-26.
Kane, T., Holmes, K.R., and O'Grady, M.A. (2007) '2007 Index of economic freedom', Heritage Foundation and The Wall Street Journal, Washington, D.C. and New York.

Kazlauskiene, A. and Rinkevicius, L. (2006) 'The role of social capital in the highly-skilled migration from Lithuania', Engineering Economics, 4(49), 69-75.

Khine, T. (2008) 'Foreign direct investment relations between Myanmar and ASEAN', Discussion Paper No. 149, April, Institute of Developing Economies, Japan External Trade Organization.

Kinnear, P.R. and Gray, C.D. (2004) SPSS 12 made simple, New York: Psychology Press.

Langford, D. (2000) 'The influence of culture on internationalisation of construction', in A.B. Ngowi, and J. Ssegawa (eds.), Challenges facing the construction industry in developing countries, proceedings of the Second International Conference of CIB TG29, 15-17 November, Gaborone, Botswana, 12-21.

Laswad, F. and Oyelere, P. B. (1999) 'An analysis of financial performance of Malaysian-based multinational enterprises', Discussion Paper No. 74, Commerce Division, Lincoln University, retrieved 9 April, 2009 from http://researcharchive.lincoln.ac.nz/ dspace/bitstream/10182/593/3/cd_dp_74.pdf.

Leamer, E. (1974) 'The commodity composition of international trade in manufacturers: An empirical analysis', Oxford Economic Papers, 26(3), 350-374.

Low, S.P. and Jiang, H. (2006) 'Analysing ownership, locational and internalisation advantages of Chinese construction MNCs using rough set analysis', Construction Management and Economics, 24(11), 1149-1165.

Luo, Y., Shenkar, O. and Nyaw, M.-K. (2002) 'Mitigating liabilities of foreignness: Defensive versus offensive approaches', Journal of International Management, 8(3), 283-300.

Mastura, J. and Abdul-Aziz, A.-R. (2005) 'Resource-based view and critical success factors: A study on small and medium sized contracting enterprises (SMCEs) in Malaysia', The International Journal of Construction Management, 5(2), 61-77.

Mayer, T. and Ottaviano, G.I.P. (2008) 'The happy few: The internationalisation of European firms: New facts based on firmlevel evidence', Intereconomics, 43(3), 135-148.

McDougall, P.P. and Oviatt, B.M. (2003) 'Some fundamental issues in international entrepreneurship', Coleman White Paper Series, 2, 1-27, retrieved 7 April, 2009 from http://www.usasbe.org.

Miller, S. and Parkhe, A. (2002) 'Is there a liability of foreignness in global banking? An empirical test of banks' X-efficiency', Strategic Management Journal, 23(1), 55-75.

Mpinganjira, M, and Rugimbana, R. (2003) 'Firm's external impediments to export involvement in Malawi', in G.N. Muuka (ed.), proceedings of IAABD 2003 - African Business and Development in the Global Economy, vol. IV, 471-477.

Narula, R. and Dunning, J. (1998) 'Explaining international R and $D$ alliances and the role of governments', International Business Review, 7(4), 377-397. 
Oz, O. (2001) 'Sources of competitive advantage of Turkish construction companies in international markets', Construction Management and Economics, 19(2), 135-144.

Peck, A., Theodore, N. and Ward, K. (2005) 'Constructing markets for temporary labour: Employment liberalization and the internationalization of the staffing industry', Global Networks, 5(1), 3-26.

Porter, M. (1990) The competitive advantage of nations, London: Macmillan Press.

Porter, M. (1994) 'The role of location in competition', Journal of Economics of Business, 1(1), 35-39.

Porter, M. (1996) 'Competitive advantage, agglomerative economies and regional policy', International Regional Science Review, 19 (1/2), 85-94.

Porter, M. (1998) 'Clusters and the new economics of competitiveness', Harvard Business Review, 76, 77-90.

Quazi, R. (2007) 'Economic freedom and foreign direct investment in East Asia', Journal of the Asia Pacific Economy, 12(3), 329-344.

Rasiah, R. (2006) 'Ownership, technological intensities, and economic performance in South Africa', International Journal of Technology Management, 36(1-3), 166-189.

Ricart, J.E., Enright, M.J., Ghemawat, P., Hart, S.L. and Khanna, T. (2004) 'New frontiers in international strategy', Journal of International Business Studies, 35, 175-200.

Seymour, H. (1987) The multinational construction industry, London: Croom-Helm.

Singer, D.A. (2004) 'Capital rules: The domestic politics of international regulatory harmonization', International Organization, 58(3), 531-565.

Solitander, A. (2005) 'States, markets, the finance lobby and the European Union savings tax directive', Accountancy Business and the Public Interest, 4(2), 28-150.

Strassmann, P. (1970) 'The construction sector in economic development', The Scottish Journal of Political Economy, 17(3), 390-410.

Sullivan, D. and Bauerschmidt A. (1990) 'Incremental Internationalisation: A test of Johanson and Vahlne's thesis', Management International Review, 30(1), 19-30.

Tashakkori, A. and Teddlie, C. (2003) Handbook of mixed methods in social and behavioural research, Thousand Oaks, California: Sage Publications.

Teddlie C. and Tashakkori A. (2003) 'The research enterprise in the social and behavioural sciences: Then and now', in A. Tashakkori and C. Teddlie (eds.), Handbook of mixed methods in social and behavioural research, Thousand Oaks, California: Sage Publications, 3-50.
Terjesen, S.A. and Acs, Z. (2007) 'Foreign direst investment and indigenous entrepreneurship: Evidence from Wales and Ireland', in proceedings of $4^{\text {th }}$ AGSE International Entrepreneurship Research Exchange 2007, 6-9 February, Brisbane, retrieved 8 April, 2009 from http://eprints.qut.edu.au/12950/1/Terjesen_2.pdf.

UNDP (2007) Malaysia small and medium enterprises: Building an enabling environment, United Nations Development Programme (UNDP), Malaysia.

Urata, S. and Kawai H. (2000) 'The determinants of the location of foreign direct investment by Japanese small and medium-sized enterprises', Small Business Economics, 15(2), 79-103.

Wang, S.Q., Dulaimi, M.F. and Aguria, M.Y. (2004) 'Risk management framework for construction projects in developing countries', Construction Management and Economics, 22(3), 237252

Wells, J. (1985) 'The role of construction in economic growth and development', Habitat International, 9(1), 55-70.

Wilkinson, I.F., Mattsson, L.-G. and Easton, G. (2000) 'International competitiveness and trade promotion policy from a network perspective', Journal of World Business, 35(3), 275-299.

Yeung, H.W-C. (1995) 'Qualitative personal interviews in international business research: Some lessons from a study of Hong Kong Transnational Corporations', International Business Review, 4(3), 313-339.

Zaheer, S. (1995) 'Overcoming the liability of foreignness', Academy of Management Journal, 38(2), 341-363.

Zaheer, S. and Mosakowski, E. (1997) 'The dynamics of the liability of foreignness: A global study of survival in financial services', Strategic Management Journal, 18(6), 439-463.

Zain, M.,and Ng, S.I. (2006) 'The impacts of network relationships on SMEs' internationalization process', Thunderbird International Business Review, 48(2), 183-205. 
[blank]

The Australasian Journal of Construction Economics and Building [Vol 9, № 1] 